F.A. Campbell MD FRCA, M.E. McLeod MD FRCPC, B. Bissonnette MD FRCPC, J.S. Swartz MD FRCPC

\section{End-tidal carbon dioxide measurement in infants and children during and after general anaesthesia}

de la tension du gaz carbonique artériel $\left(\mathrm{PaCO}_{2}\right)$ chez des nourrissons et des enfants. Une étude est réalisée d'abord à l'unité des soins postopératoires chez 40 patients: $20<12 \mathrm{~kg}$ et 20 $\geq 12 \mathrm{~kg}$. Léchantillonnage de la PETCO $\mathrm{C}_{2}$ se fait par un cathéter $16 \mathrm{G}$ de $5 \mathrm{~cm}$ fixé sous une narine et la comparaison est établie avec un prélévement artériel. Vingt patients additionnels sont étudiés pendant une anesthésie inhalatoire. $\mathrm{La} \mathrm{PETCO}_{2}$ est mesurée à la fois à l'extrémité proximale du raccord coudé et par une canule de $5 \mathrm{~cm}$ insérée a travers le raccord. (Un échantillon de sang artériel est prélevé simultanément. La différence artério-téléexpiratoire ( $P a-E T)$ est comparée au niveau des deux sites. A l'unité des soins postopératoires, la corrélation entre $\mathrm{PETCO}_{2}$ et $\mathrm{PaCO}_{2}$ est bonne et indépendante du poids: $\mathrm{Pa}_{\mathrm{ETCO}}=-0,6 \pm 3,6(<12 \mathrm{~kg})$ et $-1,1 \pm 2,8 \mathrm{~mm} \mathrm{Hg} \mathrm{P}$ $12 \mathrm{~kg}$ ). Pendant l'anesthésie au masque, la corrélation a été meilleure entre $\mathrm{PETCO}_{2}$ et $\mathrm{PaCO}_{2}$ quand la $\mathrm{PETCO}_{2}$ est prélevée par la canule: $\mathrm{Pa}-\mathrm{ETCO} \mathrm{CO}_{2}$ de 3,5 \pm 4,8 $\mathrm{mmHg}$ (canule), 8,6 $\pm 4,5$ (raccord) $(P<0,05)$. Ces résultats suggèrent que le monitorage du $\mathrm{CO}_{2}$ téléexpiratoire est utile et liable pour évaluer la suffisance de la ventilation chez des enfants pesant de 5,2 à $35 \mathrm{~kg}$.

End-tidal carbon dioxide $\left(\mathrm{PETCO}_{2}\right)$ measurement is an important monitor for identification of intraoperative ventilatory problems in children undergoing general anaesthesia with tracheal intubation and intermittent positivepressure ventilation. ${ }^{1}$ End-tidal $\mathrm{CO}_{2}$ monitoring through a tracheal tube has been studied extensively in infants and children. ${ }^{2,3}$ Monitoring of ventilation is frequently necessary in both the intra- and postoperative periods regardless of the need for tracheal intubation. The value of $\mathrm{PETCO}_{2}$ monitoring in children in whom the tracheas are not intubated has neither been established in the recovery room nor during mask anaesthesia.

Sampling end-tidal gas via a cannula inserted through nasal prongs or through a nasopharyngeal catheter has been shown to be a reliable way of monitoring $\mathrm{PETCO}_{2}$ in spontaneously breathing adults. ${ }^{4,5}$ End-tidal monitoring via a nasal sampling catheter has also been used in 
children sedated for dental procedures, but without reference to arterial $\mathrm{CO}_{2}$ tensions. ${ }^{6}$

The purpose of this study was to determine the accuracy of $\mathrm{PETCO}_{2}$ measurements in the estimation of $\mathrm{PaCO}_{2}$ in spontaneously breathing infants and children in the recovery room and during mask anaesthesia.

\section{Methods}

\section{Group I}

With approval from the Human Studies Review Committee, 40 infants and children weighing less than $35 \mathrm{~kg}$, who required indwelling arterial cannulae for intraoperative indications, were studied in the recovery room. Patients were stratified into two groups: Group Ia $<12$ $\mathrm{kg}$ and Group Ib $\geq 12 \mathrm{~kg}$. Patients with nasal obstruction, respiratory disease or right to left cardiac shunts were excluded.

On admission to the recovery room, all patients received supplementary oxygen by face mask or hood. A $5 \mathrm{~cm} 16$ gauge intravenous cannula (Angiocath, Becton Dickinson Vascular Access, Mississauga, Ont) was taped just below an external naris and connected to the sampling tube of the capnometer. The $\mathrm{PETCO}_{2}$ and oxygen saturation $\left(\mathrm{SaO}_{2}\right)$ were recorded throughout the study using a capnometer/oximeter with an aspiration rate of $200 \mathrm{ml} \cdot \mathrm{min}^{-1}$ (Model 255) and two channel chart recorder (Model DR 103) (Datex Instrumentarium Corporation, Helsinki, Finland) which were calibrated prior to each use.

The $\mathrm{O}_{2}$ flow was gradually reduced to optimize the waveform or until a minimum flow of $2 \mathrm{~L} \cdot \mathrm{min}^{-1}$ was reached. With the patient lying quietly, the $\mathrm{PETCO}_{2}$ was recorded during a 20-sec interval and an arterial blood gas sample was obtained simultaneously. The blood gas sample was immediately analyzed in a NOVA Stat Profile 5 Analyzer (NOVA, Biomedical, Waltham, Massachussetts). The $\mathrm{PETCO}_{2}, \mathrm{PaCO}_{2}$, respiratory rate, $\mathrm{O}_{2}$ flow and $\mathrm{SaO}_{2}$ were recorded and the arterial to end-tidal $\mathrm{CO}_{2}$ gradient $\left(\mathrm{Pa}-\mathrm{ETCO}_{2}\right)$ was calculated.

\section{Group II}

With approval from the Human Studies Review Committee and informed parental consent, 20 unpremedicated ASA I or II children $<12$ yr of age and $<35 \mathrm{~kg}$ in weight undergoing cystoscopy or circumcision were studied. Patients with respiratory disease and right to left cardiac shunts were excluded.

Anaesthesia was induced and maintained with halothane and nitrous oxide in oxygen using a T-piece breathing system with a gas-sampling port in the elbow connector. End-tidal gas was sampled from two sites: (i) from the sampling port of the elbow and (ii) from a $5 \mathrm{~cm}$
TABLE I Demographic data and measurements in postoperative patients

\begin{tabular}{|c|c|c|c|}
\hline & $\begin{array}{l}\text { Group la } \\
(<12 \mathrm{~kg})\end{array}$ & $\begin{array}{l}\text { Group Ib } \\
(\geq 12 \mathrm{~kg})\end{array}$ & \\
\hline Number of patients & 20 & 20 & \\
\hline Age (mo) & $15.0 \pm 9.5$ & $76.0 \pm 23.5$ & $P<0.05$ \\
\hline Weight (kg) & $9.3 \pm 2.0$ & $22.0 \pm 6.1$ & $P<0.05$ \\
\hline $\begin{array}{l}\text { Respiratory rate } \\
\text { (breaths } \cdot \min ^{-1} \text { ) }\end{array}$ & $33.0 \pm 11.0$ & $24.0 \pm 6.0$ & $P<0.05$ \\
\hline $\begin{array}{l}\text { Fresh gas flow } \\
\left(\mathrm{L} \cdot \mathrm{min}^{-1}\right) \\
\mathrm{SaO}_{2}\end{array}$ & $\begin{array}{r}4.4 \pm 1.4 \\
100.0 \pm 1.0\end{array}$ & $\begin{array}{r}5.8 \pm 0.8 \\
99.0 \pm 1.0\end{array}$ & $\begin{array}{l}P<0.05 \\
P<0.05\end{array}$ \\
\hline
\end{tabular}

16 gauge intravenous cannula inserted through the sampling port. Fresh gas flow (FGF) was adjusted to prevent rebreathing as indicated by a failure of the capnogram trace to return to baseline. After the patient was positioned for the procedure, but before surgical stimulation, an arterial blood sample was obtained and the $\mathrm{PaCO}_{2}$ was measured as in Group I. Concurrently, $\mathrm{PETCO}_{2}$ was recorded from the cannula and then directly from the sampling port in the elbow with the cannula removed. End-tidal $\mathrm{CO}_{2}$ readings were recorded for ten seconds at each of the sample sites. When a plateau was not obtained, the peak value of the $\mathrm{PETCO}_{2}$ was recorded. ${ }^{3}$ Respiratory rate, $\mathrm{FGF}$ and $\mathrm{SaO}_{2}$ were also recorded. The arterial to end-tidal differences were subsequently calculated.

\section{Statistics}

Parametric data are reported as mean \pm SD. In the postoperative groups, demographic and parametric variables were compared using the unpaired $t$ test. In the intraoperative group, the arterial to end-tidal $\mathrm{CO}_{2}$ differences obtained at the elbow connector and at the tip of the $5 \mathrm{~cm}$ cannula were compared using paired $\mathrm{t}$ tests. Statistical significance was accepted as $P<0.05$.

\section{Results}

Group Ia differed from Group Ib with respect to age, weight, respiratory rate and fresh gas flow $(P<0.05)$ (Table I). Fresh gas flow was reduced below $4 \mathrm{~L} \cdot \mathrm{min}^{-1}$ in only one of the $\mathbf{4 0}$ patients. In Group Ia the patients ranged in weight from 5.2 to $11.7 \mathrm{~kg}$ and in Group Ib, from 12.8 to $34.7 \mathrm{~kg}$. However, mean $\mathrm{PaCO}_{2}, \mathrm{PETCO}_{2}$ and arterial to end-tidal differences were clinically similar (Table II). There were ten patients with negative arterial to end-tidal gradients in Group Ia $(<12 \mathrm{~kg})$ and twelve in Group Ib.

The patients in Group II ranged in age from five months to $9.25 \mathrm{yr}$ and in weight from $7.2-29.0 \mathrm{~kg}$ (Table III). Arterial $\mathrm{CO}_{2}$ tension ranged from $42.0-54.7 \mathrm{mmHg}$ 
TABLE II Arterial end-tidal and a-ET $\mathrm{CO}_{2}$ differences in postoperative patients

\begin{tabular}{lrrl}
\hline & \multicolumn{1}{c}{ Group Ia } & \multicolumn{1}{c}{ Group Ib } & \\
\hline $\mathrm{PaCO}_{2}(\mathrm{mmHg})$ & $38.6 \pm 5.0$ & $39.0 \pm 5.6$ & NS \\
$\mathrm{PETCO}_{2}(\mathrm{mmHg})$ & $39.3 \pm 4.5$ & $40.1 \pm 4.7$ & NS \\
${\mathrm{Pa}-\mathrm{ETCO}_{2}(\mathrm{mmHg})}$ & $-0.65 \pm 3.6$ & $-1.15 \pm 2.8$ & NS \\
\hline
\end{tabular}

TABLE III Demographic data and measurements during mask anaesthesia

\begin{tabular}{|c|c|}
\hline Number & 20 \\
\hline Age & $45.6 \pm 38.6 \mathrm{mo}$ \\
\hline Weight & $15.8 \pm 7.21 \mathrm{~kg}$ \\
\hline Fresh gas flow & $6.4 \pm 1.3 \mathrm{~L} \cdot \mathrm{min}^{-1}$ \\
\hline Respiratory rate & $48.0 \pm 10$ breaths $\cdot \mathrm{min}^{-1}$ \\
\hline $\mathrm{Pa-ETCO}{ }_{2}$ (elbow) & $8.6 \pm 4.5 \mathrm{mmHg}$ \\
\hline Pa-ETCO 2 (cannula) & $3.5 \pm 4.8 \mathrm{mmHg}^{*}$ \\
\hline
\end{tabular}

* $P<0.001$ compared to Pa-ET (elbow).

and was more closely approximated by end-tidal measurements through the cannula than at the elbow connector site $(P<0.05)$ (Table III). Negative gradients occurred in two patients.

There were no complications associated with either phase of the study.

\section{Discussion}

This study shows that end-tidal $\mathrm{CO}_{2}$ sampling can provide a continuous estimate of $\mathrm{PaCO}_{2}$ in spontaneously breathing infants and children both during mask anaesthesia and in the post-anaesthetic care unit.

In postoperative patients, sampling at the external naris provided a good estimate of $\mathrm{PaCO}_{2}$ regardless of weight. The use of end-tidal $\mathrm{CO}_{2}$ measurement to estimate $\mathrm{PaCO}_{2}$ in infants has been fraught with difficulties because of small tidal volumes, high respiratory rates and relatively high fresh gas flows during anaesthesia. Badgwell et al. showed that, in patients $<12 \mathrm{~kg}$ with a tracheal tube in place and ventilated with intermittent positive pressure, $\mathrm{Pa}-\mathrm{ETCO}_{2}$ was greater than in larger children unless sampling was done in the distal airway. ${ }^{2}$ This study, however, demonstrates that the value of $\mathrm{PETCO}_{2}$ as an estimate of $\mathrm{PaCO}_{2}$ in the spontaneously breathing, infant $\leq 12 \mathrm{~kg}$ is not different from measurement in the larger child.

The addition of the cannula to the end-tidal sampling line provided a better estimate of $\mathrm{PETCO}_{2}$ in infants and children undergoing mask anaesthesia than did measurement obtained at the top of the elbow sampling port. The improvement in accuracy of end-tidal measurement is somewhat surprising since the sampling site was not extended into the distal airway as in previous studies of intubated patients. ${ }^{2,3}$ Recent work by Halpern $e t$ al. has demonstrated that considerable dilution by fresh gas does not extend beyond the connector of the endotracheal tube and it therefore may not be necessary to sample at the distal end of the tube. ${ }^{7}$ Similarly, in the patient breathing spontaneously during mask anaesthesia, it appears that the addition of a $5 \mathrm{~cm}$ cannula at the sampling port of the elbow to extend the sampling site to the mask is sufficient to produce a significant improvement in end-tidal $\mathrm{CO}_{2}$ measurement.

The number of negative a-ET differences, particularly in the postoperative group, is of interest. Rich, in a study of neonates in whom the tracheas were intubated and lungs ventilated, found a negative gradient in 7 of 14 infants. ${ }^{8}$ In this situation, negative gradients are likely related to larger than normal tidal volumes which allow gas from "slow alveoli" to reach the mouth and result in better ventilation of dependent alveoli. ${ }^{9}$ Although large tidal volumes may be a factor in the awake, crying infant, this would not be expected to play a large role in our postoperative patients since recordings were made during quiet breathing. Negative gradients have also been observed in spontaneously breathing adults. ${ }^{10}$ McNulty et $a l$. in their study found that the largest negative gradients were associated with sudden increases in $\mathrm{PaCO}_{2} \cdot{ }^{10}$ Since a single measurement of $\mathrm{PaCO}_{2}$ was made in the present study, we are unable to confirm the occurrence of this phenomenon in children, but it may have played a role. Overestimation of $\mathrm{PETCO}_{2}$ may also be the result of interference of water vapour in the measurement of $\mathrm{CO}_{2}$ by an infra-red analyzer. Although Severinghaus has described a method of correcting measurements to BTPS (body temperature and pressure, saturated) ${ }^{11}$ it is difficult to make an appropriate correction for water vapour at body temperature in the present investigation as the sampling site is not within the airway. Déry has shown that both temperature and relative humidity change considerably from carina to mouth. ${ }^{12}$

This study demonstrates that end-tidal monitoring in healthy infants and children breathing spontaneously during mask anaesthesia or in the postanaesthetic care unit is useful over the usual clinical range of $\mathrm{PaCO}_{2}$. It also suggests that this method of end-tidal gas sampling may prove helpful during conscious sedation, neuroleptanalgesia and regional anaesthesia techniques.

\section{Acknowledgement}

We acknowledge the support of the Puritan-Bennett Corporation in the performance of this study.

\section{References}

1 Coté CJ, Rolf N, Liu LMP, et al. A single-blind study of 
combined pulse oximetry and capnography in children. Anesthesiology 1991; 74: 980-7.

2 Badgwell JM, McLeod ME, Lerman J, Creighton RE. End-tidal $\mathrm{PCO}_{2}$ measurements sampled at the distal and proximal ends of the endotracheal tube in infants and children. Anesth Analg 1987; 66: 959-64.

3 McEvedy BAB, McLeod ME, Mulera M, Kirpalani $H$, Lerman J. End-tidal, transcutaneous, and arterial $\mathrm{PCO}_{2}$ measurements in critically ill neonates; a comparative study. Anesthesiology 1988; 69: 112-6.

4 Lenz G, Heipertz W, Epple E. Capnometry for continuous postoperative monitoring of nonintubated, spontaneously breathing patients. J Clin Monit 1991; 7: 245-8.

5 Roy J, McNulty SE, Torjman MC. An improved nasal prong apparatus for end-tidal carbon dioxide monitoring in awake, sedated patients. J Clin Monit 1991; 7: 249-52.

6 Iwasaki J, Vann WF Jr, Dilley DCH, Anderson JA. An investigation of capnography and pulse oximetry as monitors of pediatric patients sedated for dental treatment. Pediatric Dentistry 1989; 11: 111-7.

7 Halpern L, Bissonnette B. Visualizing the mixing of fresh gas and expired gas in the Mapleson D circuit: a laboratory model. Anesthesiology 1991; 75: A421.

8 Rich GF, Sconzo JM. Continuous end-tidal $\mathrm{CO}_{2}$ sampling within the proximal endotracheal tube estimates arterial $\mathrm{CO}_{2}$ tension in infants. Can J Anaesth 1991; 38: 201-3.

9 Fletcher $R$, Jonson $B$. Deadspace and the single breath test for carbon dioxide during anaesthesia and artifical ventilation. Br J Anaesth 1984; 56: 109-18.

10 McNulty SE, Roy J, Torjman M, Seltzer JL. Relationship between arterial carbon dioxide and end-tidal carbon dioxide when a nasal sampling port is used. J Clin Monit 1990; 6: 93-8.

11 Severinghaus JW. Water vapor calibration errors in some capnometers: respiratory conventions misunderstood by manufacturers? Anesthesiology 1989; 70: 996-8.

12 Déry $R$. The evolution of heat and moisture in the respiratory tract during anaesthesia with a non-rebreathing system. Can Anaesth Soc J 1973; 20: 296-309. 